THE ALLOCATIVE EFEICIENCY MEASURE BY MEANS OF A DISTANCE FUNCTION: THE CASE OF SPANISH PUBLIC RAILWAYS.

$$
\text { Doc. } 181 / 99
$$

José Baños-Pino

Víctor Fernández-Blanco

Ana Rodríguez-Álvarez 


\title{
THE ALLOCATIVE EFFICIENCY MEASURE BY MEANS OF A DISTANCE FUNCTION: THE CASE OF SPANISH PUBLIC RAILWAYS
}

\author{
Authors: \\ José Baños-Pino \\ Victor Fernández-Blanco \\ Ana Rodriguez-Álvarez \\ University of Oviedo
}

* We would like to thank T. Coelli, P. Schmidt and K. Lovell for their helpful comments and/or suggestions. We would also like to thank the participants at the Workshop on Productivity Analysis, held at the University of Oviedo in June 1998 for their contributions, especially Antonio Pinilla. As usual, a disclaimer applies. 


\section{INTRODUCTION}

The aim of this paper is to verify whether there exists allocative efficiency in the Spanish public railways: RENFE. To do this, we analyse whether the proportion of productive factors chosen by the firm, with specific technology and given prices, is the most appropriate in order to minimise costs. The neo-classical model in production theory starts from the hypothesis of minimum cost production for firms; see for example McGeehan (1993) and Friedlaender et al. (1993) for railway systems. However, nowadays there are more and more studies which are sceptical of this hypothesis of cost minimising behaviour and study the problems of the allocative efficiency in companies, especially in the regulated sector and the public sector (Toda (1976), Atkinson and Halvorsen (1986), Domenech (1993), Grosskopf and Hayes (1993), Grosskopf et al. (1995) and Bosco (1996)).

In these latter three studies the allocative efficiency was investigated using a new methodology: a Shephard (1953) input distance function. This function has a series of advantages over the functions of production and cost. With reference to the first, the distance function is valid for various outputs, which justifies its usage in the case of a multioutput firm such as RENFE. Compared with the cost function, the distance function offers three advantages. Firstly, it does not imply cost minimisation. Secondly, it requires neither information on input prices nor the assumption of these being exogenous. This is of great relevance in the context of the public sector where there are often distinct control mechanisms on input prices. The third advantage is that the 
distance function allows us to directly obtain a measure of allocative inefficiency independent of the degree of technical inefficiency. ${ }^{1}$

Because of this, an input distance function is used with the objective being to check, taking into account the productivity and the relative prices of the distinct factors of production, whether the input allocation has been efficient in RENFE or, if this is not the case, what inputs are being relatively under or overutilised. Besides, in contrast with other studies which have calculated allocative inefficiency using an input distance function (Grosskopf and Hayes, 1993, Atkinson et al. 1998), we assume that the employment of an input in a proportion different from that which would minimise cost could be systematic, and incorporate this possibility into our empirical model. By doing this we can obtain not only a measure of relative allocative inefficiency but also a measure of absolute allocative inefficiency.

The sample period studied covers the years 1955-1995. During this period, railway transport in Spain was operated and managed by a single company, RENFE, which operates goods and passenger transport services in a quasi-monopoly regime. ${ }^{2}$ There are reasons to question the fact that, in RENFE, resources are allocated in an efficient way. In 1984, a Government Commission carried out a report which highlighted the lack of competitiveness of the firm. In this report the relatively minor

\footnotetext{
'Although the objective of our work is to study allocative efficiency, the methodology of the distance function also enables us to calculate technical efficiency (see for example Coelli, 1996 and Atkinson et al., 1998). There are many studies in the literature on the railway sector which analyse the technical efficiency using production frontiers (for example, Perelman and Pestieau, 1988; Gathon and Pestieau, 1992 and Gathon and Pestieau, 1995).

${ }^{2}$ Although other railways companies exist in Spain (FEVE, FFCC, those of the Catalan Generalitat, the Autonomous Government of Valencia, the Basque Provinces, the Balearic Islands Autonomous Communities and private companies), RENFE accounted for $92 \%$ and $96 \%$ of total travellers and goods traffic respectively during 1995 .
} 
share of inter-city transport accounted for by the railway is shown: the average shares accounted for by RENFE were $8.5 \%$ in passengers and $8 \%$ in goods, in contrast to European averages of $10 \%$ and $24 \%$ respectively. These shares began to decline in the 1950 s and this process continued until the late 1970s. Regulation made it practically impossible to reduce services and close lines and prevented the network size being adjusted to changes in the market (De Rus, 1989). On the other hand, transport service prices are fixed by the Administration, with the criterion that fares evolve in accordance with production costs and service quality. Moreover, it had been established as a general rule that operating revenues shall cover costs. This type of regulation could result in a lack of incentives in managerial activities to minimise costs.

Since the 1980 s a series of measures have been observed which have tended to reduce capacity excess problems and the inefficiency the company was experiencing (Carbajo and De Rus, 1991). Several management contracts were agreed in which the State established objectives to be achieved by the company as a condition for the granting of subsidies, including a set of economic-fmancial objectives closely bound to a policy of adjustment which included staff reduction and the closing of lines which showed a high level of deficit. For example, the management contract in 1984-1986 provided an agreement to close $882 \mathrm{~km}$ of lines and to reduce the workforce by 15,000 in the space of four years. Subsequently, the 1988-1991 management contract designed a new fare system with the aim of achieving a financial clean-up. Finally, in 1994 another management contract was approved, which provided for cost-reduction, revenue increase and improvements in asset turnover. Furthermore, headway has been made towards the consolidation of business units as the basic instruments to manage the 
activity of RENFE, each being fixed with objectives and incentives. ${ }^{3}$

Our research provides empirical evidence on how these policies -reallocation of resources and management incentives- have affected company efficiency levels, favouring a better input allocation, given productivity and their relative price levels. Furthermore, the estimation carried out allowed us to calculate the Morishima elasticities of substitution.

The structure of the paper is as follows. In Section 2 the theoretical model is presented. In Sections 3 and 4 there is an explanation of the methodology used for the estimation of the shadow prices by means of the Shephard distance function. Section 5 concerns itself with the econometric model. In Section 6 we describe the data set that we used. Section 7 reports the empirical results. Finally, in Section 8 we present a brief summary and conclusions.

\section{THE THEORETICAL MODEL}

Neo-classical production theory starts from the hypothesis of minimum cost production by firms. According to this hypothesis, the existence of allocative efficiency implies that the firm hires inputs $x_{i}$ and $x_{j}$ in a combination such that their respective prices $\left(w_{i}\right.$ and $\left.w_{j}\right)$ equal their respective marginal revenue product $\left(M R P_{i}\right.$ and $\left.M R P_{j}\right)$. In

\footnotetext{
${ }^{3}$ The present management structure of RENFE is comprised of the following business units: Suburban, Regional, Long Distance and High Speed for passenger services, and Freight, Intermodal, Traction and Rolling Stock Maintenance for the remaining.
} 
relative terms:

$$
\frac{M R P_{1}}{M P R_{j}}=\frac{w_{i}}{w_{j}}
$$

However, this condition may not be satisfied if costs are not being minimised with respect to market prices, but with respect to others which are called shadow prices. Recently many empirical studies which question the above hypothesis have appeared: Eakin and Kniesner (1988), Grosskopf and Hayes (1993) or Grosskopf et al. (1995), are some examples. In our theoretical set-up we try to explain the existence of these shadow prices in a public company like RENFE, and their relationship with market prices.

\subsection{Formalisation of the theoretical model}

The theoretical model is based on the hypothesis of maximisation of management utility, as an altemative objective to the maximisation of profits (Williamson, 1963 and Niskanen, 1968). Under this hypothesis, and following Atkinson and Halvorsen (1986), the company management utility function can be formalised as a function of two variables, profit and the quantity of inputs. The maximisation problem is:

$$
\begin{aligned}
& \max U=U(P, x) \\
& \text { s.t. } P=R(x) \cdot \sum_{i=1}^{n} w_{i} x_{i}
\end{aligned}
$$

where:

$U()=$. is a twice continuously differentiable quasi-concave utility function.

$P \quad=$ profits obtained by the firm

$x=$ is the vector of inputs 


$$
\begin{aligned}
& R=\text { firm revenue. It is assumed that revenue is a function of } \\
& \text { output, so } R=g(y) \text {, where } y \text { is the vector of outputs. Moreover, } \\
& \text { since } y=f(x) \text {, this can be written as } R=g\{f(x)\} . \\
& w_{i}=\text { market price of } i \text { input. } \\
& x_{i}=\text { quantity of } i \text { input }(i=1 \ldots n)
\end{aligned}
$$

It is assumed that $\partial U / \partial P>0$, and $\partial U / \partial x \geq$ or $<0$ depending on the given input. That is to say, there will be inputs which yield a positive utility (i.e. "visible" inputs as staff, sophisticated machinery, etc.), others that yield negative utility (i.e. those which imply a bigger effort on the part of the manager) and others that are neutral.

The solution for the maximisation problem is expressed through the Lagrangian:

$$
L(P, x, \lambda)=U(P, x)-\lambda\left[P-R(x)+\sum_{i} w_{i} x_{i}\right]
$$

From this, we find that marginal revenue value for the th input is equal to:

$$
\frac{\partial R}{\partial x_{i}}=w_{i}-\frac{\frac{\partial U}{\partial x_{i}}}{\frac{\partial U}{\partial P}}=w_{i}^{s}
$$

where $w_{l}^{s}$ is the shadow price of input $i$. Hence, $w_{1}^{3}$ differs from $w_{l}$ by the effects of the manager's behaviour.

Dividing the marginal revenue product of input $i$ by that of input $j$, we get:

$$
\frac{\frac{\partial R}{\partial x_{i}}}{\frac{\partial R}{\partial x_{j}}}=\frac{\frac{\partial R}{\partial y_{1}} \frac{\partial y_{1}}{\partial x_{1}}+\ldots+\frac{\partial R}{\partial y_{m}} \frac{\partial y_{m}}{\partial x_{1}}}{\frac{\partial R}{\partial y_{1}} \frac{\partial y_{1}}{\partial x_{j}}+\ldots+\frac{\partial R}{\partial y_{m}} \frac{\partial y_{m}}{\partial x_{j}}}=\frac{M R P_{1}}{M R P_{j}}=\frac{w_{1}^{s}}{w_{j}^{s}}
$$

where $y_{r}$ is the quantity of output $r(r=1 \ldots m)$. 
Consequently:

$$
\frac{M R P_{i}}{M R P_{j}}=\frac{w_{i}^{s}}{w_{j}^{s}}
$$

In contrast to equation (1), the necessary condition for cost minimisation can be satisfied with regard to shadow prices $\left(w^{s}\right)$ which may differ from market prices.

\subsection{Theoretical model conclusions.}

Some interesting conclusions can be derived from the above analysis (see equation 5):

1. The difference between $w$ and $w^{3}$ will inversely depend on the magnitude of the marginal utility of profit, $\partial U / \partial P$. When $\partial U / \not \mathcal{P}$ is high (low), that is, when more (less) incentives exist to maximise profit, it will tend to be more (less) cost efficient.

2. The difference between $w$ and $w^{3}$ will also depend on the magnitude of the relationship between managers' utility and inputs $\left(\partial U / 2 x_{i}\right)$.

3. Moreover, relative comparisons of inputs can be obtained. For instance, if $w_{i}^{3}>w_{1}$ and $w_{j}^{3}<w_{i}$ then the $i$ input will be underutilised relative to $j$ input and viceversa .

The inconvenience of this model arises due to the fact that the shadow prices are not observable, and from equation (5) a difficult relationship between shadow prices and market prices is obtained, since the utility function is unknown. Therefore it is necessary to introduce a more simplified relationship between both. To achieve this 
objective a Shephard distance function is introduced (Färe and Grosskopf (1990)).

\section{THE DISTANCE FUNCTION}

Formally, given any two vectors $x$ and $y$, the Shephard (1953) input distance function is defined as follows:

$$
D_{I}(x, y)=\max _{\delta}(\delta \geq 1:(x / \delta) \in L(y))
$$

where:

$y\left(y_{1} \ldots y_{n}\right)=$ is the vector of outputs

$x\left(x_{1} \ldots x_{n}\right)=$ is the vector of inputs.

$L(y)=\left(x \in R_{n}^{+}: x\right.$ can produce $\left.y \in R_{m}^{+}\right)$.

To explain the distance function graphically, we consider the case (Figure 1) where a firm which produces a single output $(y)$ that uses two production factors $\left(x_{l}\right.$ and $\left.x_{2}\right)$.

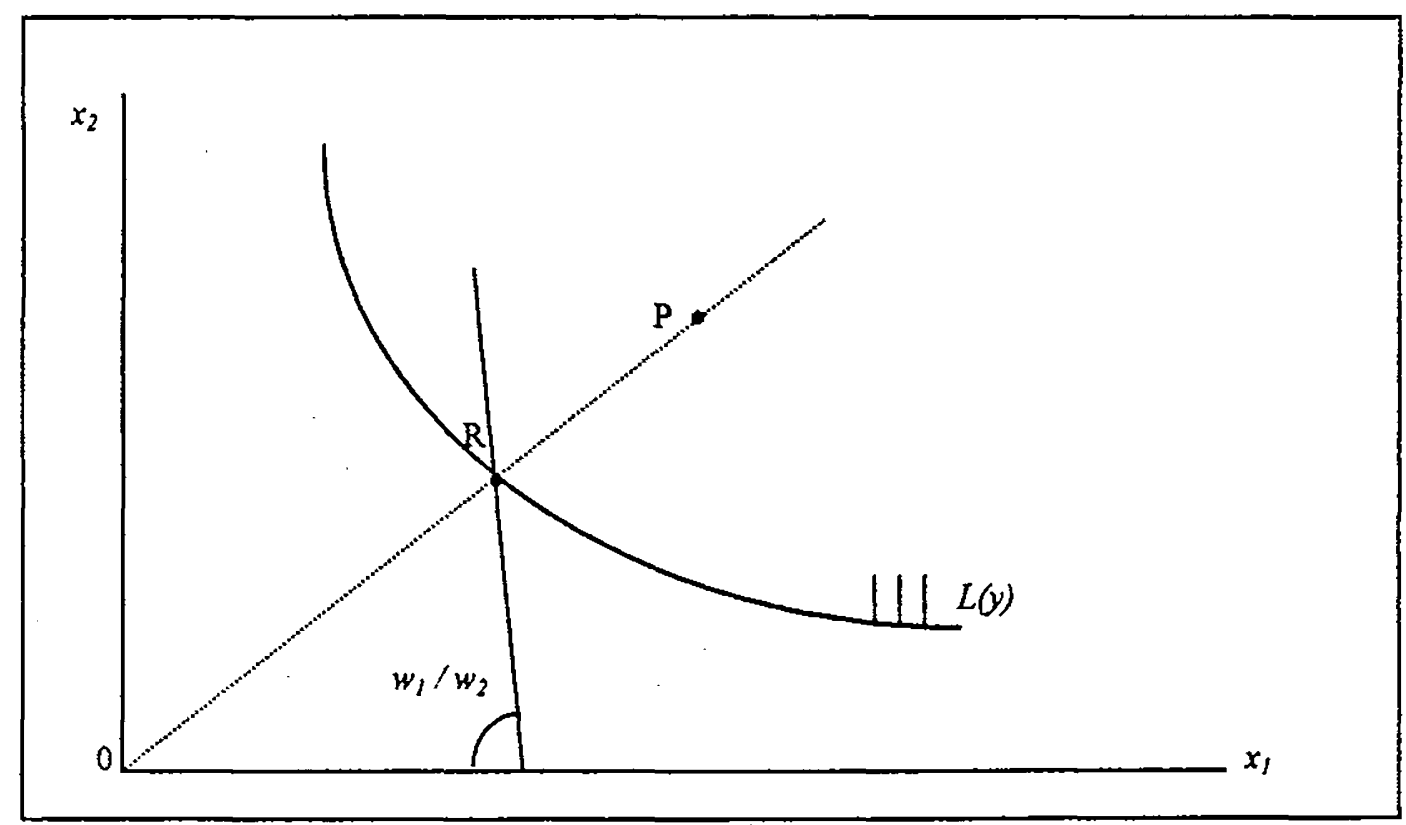

Figure 1 
The ratio OR/OP is the Farrell (1957) radial measure of technical efficiency (TE) for the point $P$. It signifies the maximum proportional reduction that can be achieved in the utilised inputs which still allows production of the same amount of output. Formally:

$$
\operatorname{TE}(\mathrm{x}, \mathrm{y})=\min _{\lambda}(\lambda \in(0,1): \lambda \mathrm{x} \in L(y))
$$

The maximum value of this index is one, which means that the firm is operating on the isoquant and thus technically efficient. A value lower than one (as can be seen in Figure 1) informs us about of degree the technical efficiency achieved by the firm. It can be seen that from reciprocal of the index we obtain the definition of the distance function, that is, OP/OR represents the largest scalar by which all factors can be divided proportionally and continue producing the same output level.

Evidently $x \in \mathrm{L}(y)$, if and only if $D_{l}(x, y) \geq 1$. If $D_{1}$ equals one, it means that production is technically efficient. A higher value than one informs us about the degree of efficiency achieved. ${ }^{4}$

The Shephard input distance function satisfies the following properties: ${ }^{5}$

(1) $D_{I}(x, y)$ is dual of the cost function

(2) $D_{I}(x, y)$ is decreasing in each output level

(3) $D_{l}(x, y)$ is increasing in each input level

\footnotetext{
${ }^{4}$ We could also define an output distance function which is the maximum possible proportional increment in the output vector, with the given inputs vector and technology. Applications of this type of function can be found in English et al. (1993) and Grosskopf et al. (1995b).

${ }^{3}$ Proofs of these properties can be found in Cornes (1992).
} 
(4) $D_{l}(x, y)$ is homogeneous of degree 1 in $x$

(5) $D_{I}(x, y)$ is concave in $x$

\section{ESTIMATION OF SHADOW PRICES BY MEANS OF A SHEPHARD DISTANCE FUNCTION}

Initially, studies using shadow prices to obtain a measure of allocative efficiency were based on the estimation of a system of equations formed by a shadow cost function and the set of cost share equations (Atkinson and Halvorsen (1986), Eakin and Kniesner (1988), Domenech (1993)). This equations system had the property of establishing a relationship between shadow prices and market prices using the appropriate parametric corrections in input prices, to satisfy the cost minimisation condition.

Färe and Grosskopf (1990) study an alternative method to get shadow prices out of inputs using Shephard's distance function, providing themselves thereby with analysis of firm cost efficiency. Distance function has the advantage over the first method that in order to estimate distance function, data about factors prices are not necessary.

Färe and Grosskopf (1990) assume that the firm minimises costs with respect to certain shadow prices that may differ from market prices. Therefore, the cost function can be defined as:

$$
C\left(y, w^{s}\right)=\min _{x}\left(w^{s} x: x \in L(y)\right)=w^{s} x\left(y, w^{3}\right)
$$

where $w_{i}^{s}$ is shadow price of factor $i$ for which the cost minimisation condition would be satisfied. 
Applying duality theory to the cost function and distance function ${ }^{6}$, Farre and Primont (1990) derive the dual Shephard's lemma:

$$
\frac{\partial_{I}(x, y)}{2 x}=\frac{w^{s}}{C\left(y, w^{s}\right)}
$$

That is, the derivative of the distance function with respect to an input is the normalised shadow price. From (11), with any two given inputs $i, j=1,2, \ldots, \mathrm{n}$, the shadow price ratio is obtained:

$$
\frac{\frac{\partial D_{I}(x, y)}{\partial x_{i}}}{\frac{\partial D_{I}(x, y)}{\partial x_{j}}}=\frac{w_{i}^{s}(y, x)}{w_{j}^{s}(y, x)}
$$

Now, if the cost-minimisation assumption is satisfied, this normalised shadow price ratio should be the same as the input market price ratio. However, if inputs are not selected in the appropriate proportion, that is to say, if allocative inefficiency occurs, the aforementioned price ratios will differ.

To study the quantity and direction of such a deviation, a relationship between the normalised shadow prices obtained through the distance function and the input market prices is introduced by means of a parametric price correction (Eakin and Kniesner (1988) and Färe and Grosskopf (1990)):

$$
w^{s}(x, y)=k_{i} w_{i}
$$

Dividing this expression (13) by that corresponding to input $j$ we obtain:

$$
\frac{w_{i}^{s}(x, y)}{w_{j}^{s}(x, y)}=k_{i j} \frac{w_{i}}{w_{j}}
$$

\footnotetext{
${ }^{6}$ The duality between the distance function and cost function is explain in Färe and Primont (1995).
} 
where:

$$
k_{i j}=\frac{k_{i}}{k_{j}}
$$

Thus, from (14) the degree to which the shadow prices differ from the market prices is calculated. Moreover, we can obtain the direction of such inefficiency as follows:
(a) If $k_{i j}=1$, there is allocative efficiency in relative terms.
(b) If $k_{i j}>1$, the factor $i$ is being underutilised relative to the $j$ factor.
(c) If $k_{l j}<1$, the factor $i$ is being overutilised relative to the $j$ factor.

As can be observed in Figure 2, the normalised shadow price ratio would indicate the isocost slope if costs were actually minimised with the chosen input proportion. That is to say, the isocost with slope $\frac{w_{1}^{t}(x, y)}{w_{2}^{t}(x, y)}$ tells us what prices (shadow prices) would minimise costs to produce output $y$, with the observed input bundle and given technology.

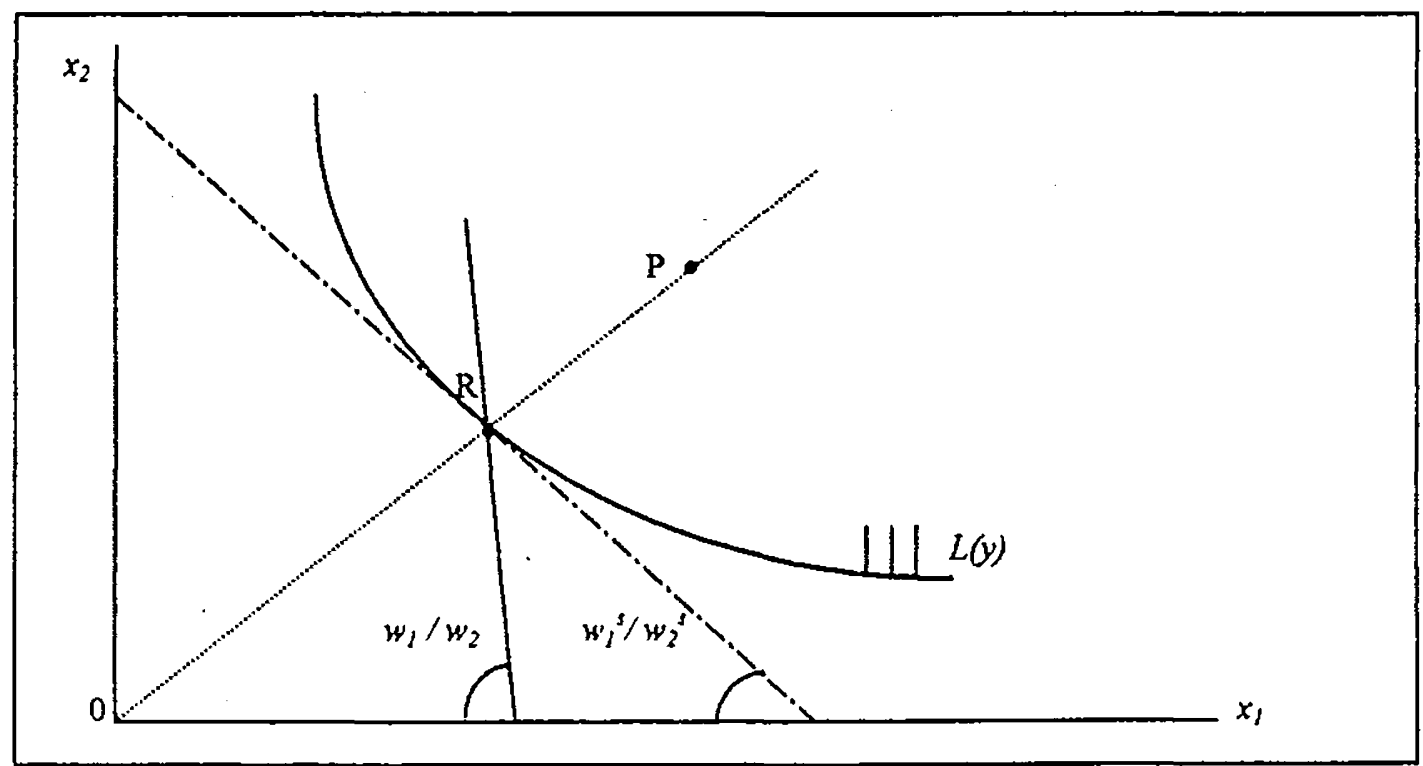

Figure 2 
Starting with Färe and Grosskopf (1990), there have been numerous studies in which the distance function has been used as a means to check allocative efficiency in production: Grosskopf and Hayes (1993) and Grosskopf et al. (1995) are some examples.

Next, we turn to applying this methodology to RENFE. For this we begin by proposing the econometric model. In our study, we also obtain a measure of absolute allocative inefficiency. We discuss this in detail in the empirical results section.

\section{THE ECONOMETRIC MODEL}

To obtain the shadow prices of productive factors, we propose estimating an translog input distance function. To improve the efficiency of the estimation process, the input distance function will be estimated jointly with the cost share equations, which we can obtain by differentiating the translog distance function with respect to $\ln x_{i}$.

One of the difficulties in estimating this model is that the distance function value $D_{l}(x, y)$ is not known. To solve this problem, we assume that its value is, for instance, equal to one which implies the assumption of technical efficiency. Of course, this is not necessary, since the distance function is homogeneous of degree one in inputs and the cost share equations are homogeneous of degree zero in productive factors. That is, the measure of allocative inefficiency that it is obtained by means of a translog input distance function is independent of the degree of technical inefficiency. ${ }^{7}$

${ }^{7}$ Technical efficiency affects only the intercept of the translog distance function. Consequently, the derivatives of the distance function with respect to inputs are independent of the degree of technical inefficiency. 
Thus, the set up model is as follows:

$$
\begin{gathered}
\ln l=\ln D_{I}(x, y) \\
\frac{\partial \ln D_{I}(x, y)}{\partial \ln x_{i}}=\frac{\partial D_{l}(x, y)}{\partial x_{i}} \frac{x_{i}}{D_{l}(x, y)}=\frac{w^{s}}{C\left(y, w^{s}\right)} x_{i}=W_{i}^{s} x_{i} \quad(i=l, \ldots, n)
\end{gathered}
$$

To estimate the distance function it is necessary to select a determined functional form. In doing so, a series of characteristics are being imposed on the technology without exact knowledge as to whether or not such properties are true or false. For this reason it is especially advantageous to use flexible functional forms that impose the least possible restrictions on the technology that one is trying to describe. Due to this we have used a Translog multiproduct function.

In short, the Shephard input distance function is defined as:

$$
\begin{aligned}
\operatorname{Ln} 1=\alpha_{0} & +\sum_{r=1}^{m} \alpha_{r} \ln y_{r}+\frac{1}{2} \sum_{r=1}^{m} \sum_{s=1}^{m} \alpha_{r s} \ln y_{r} \ln y_{s}+\sum_{i=1}^{n} \beta_{i} \ln x_{i}+ \\
& +\frac{1}{2} \sum_{i=1}^{n} \sum_{j=1}^{n} \beta_{i j} \ln x_{i} \ln x_{j}+\sum_{r=1}^{m} \sum_{i=1}^{n} \rho_{r i} \ln y_{r} \ln x_{i}+\varepsilon
\end{aligned}
$$

The cost share equations of each input $i$ are given as :

$$
\frac{x_{i} w_{i}}{C}=\beta_{i}+\sum_{j=1}^{n} \beta_{i j} \ln x_{j}+\sum_{r=1}^{m} \rho_{n} \ln y_{r}+u_{i}
$$

for $r, s=1, \ldots, \mathrm{m}$ outputs; $i, j=1, \ldots, \mathrm{n}$ inputs, and where $\varepsilon$ is the random disturbance term and $C$ represents total cost. The dependent variable in (19) is $\frac{x_{1} w_{1}}{C}$, so errors in the share equations system indicate the cost of allocative inefficiency.

Given that the dependent variable in the distance function equation is $\ln 1=0$, estimation can be carried out if a nonzero linearity of the parameters is imposed. 
Therefore, the conditions required by the theory (see section 3.1) have been imposed:

a) homogeneity of degree one:

$$
\sum_{i=1}^{n} \beta_{i}=1 \quad \sum_{j=1}^{n} \beta_{i j}=0 \quad \sum_{r=1}^{m} \rho_{r i}=0
$$

b) and symmetry:

$$
\beta_{i j}=\beta_{j l}
$$

According to our model, the proportionality factors $\left(k_{i i}\right)$ can be derived from equations (14) and (12):

$$
k_{b}=\frac{\frac{w_{l}^{s}(x, y)}{w_{j}^{s}(x, y)}}{\frac{w_{l}}{w_{j}}}=\frac{\frac{\frac{\partial D_{l}(x, y)}{\partial x_{i}}}{\frac{D_{l}(x, y)}{\partial x_{j}}}}{\frac{w_{l}}{w_{j}}}
$$

Taking into account that we specified the distance function in terms of logarithms, from (17) we get:

$$
\frac{\partial D_{l}(x, y)}{\partial x_{i}}=\frac{\partial \ln D_{l}(x, y)}{\partial \ln x_{i}} \frac{D_{l}(x, y)}{x_{i}}=\left[\text { as } D_{l}(x, y)=1\right]=\frac{\partial \ln D_{l}(x, y)}{\partial \ln x_{i}} \frac{1}{x_{i}}(21)
$$

Substituting (21) into (20) and using (19) we get that:

$$
k_{i j}=\frac{\frac{\frac{\partial \ln D_{l}(x, y)}{\partial \ln x_{i}} \frac{1}{x_{i}}}{\frac{\partial \ln D_{l}(x, y)}{\partial \ln x_{j}} \frac{1}{x_{j}}}}{\frac{w_{i}}{w_{j}}}=\frac{\frac{w_{j}}{x_{i}}\left[\hat{\beta}_{i}+\sum_{j=1}^{n} \hat{\beta}_{i j} \ln x_{j}+\sum_{r=1}^{m} \hat{\rho}_{r i} \ln y_{r}\right]}{\frac{w_{i}}{x_{j}}\left[\hat{\beta}_{j}+\sum_{i=1}^{n} \hat{\beta}_{i j} \ln x_{i}+\sum_{r=1}^{m} \hat{\rho}_{r i} \ln y_{r}\right]}
$$




\section{DATA}

The railway activity is a multiproduct one, since not only can we distinguish between passenger and freight transport, but also such other products as originsdestinations which exist in the railroad network. However, the lack of data has led us to consider only two outputs: kilometres covered by travellers (millions of travellers-km transported) and kilometres covered by goods. With respect to the latter, only the pure traffic which includes tons (in millions) of commercial goods per kilometre has been considered. ${ }^{8}$ Thus, our variables $\mathrm{Fkm}$ and Pkm measure the outputs freight-tonnage per kilometre and passengers per kilometre, respectively.

Three inputs have been considered: Labour (L), Capital (K), and Energy (E). Labour includes both permanent and temporary personnel. The labour cost is the personnel expense in millions of current pesetas. For the energy variable, motor equipment energy consumption has been used, in thousand million kilocalories. ${ }^{9}$ The energy cost is the energy and fuels expenditure in millions of current pesetas each year.

As for the capital series, we have considered physical units of motor equipment which includes, during the sample period, electric, diesel, and steam locomotives, as well as electric and diesel trains. Starting from the data provided in Muñoz Rubio (1995) and from RENFE reports, we have constructed, firstly, the age structure of each type of haulage unit which was in service in each year. Then, these have been

\footnotetext{
${ }^{8}$ The post is included while the suppliers traffic and the interior service are excluded.

${ }^{9}$ In energy-equivalent terms.
} 
depreciated according to their years of service, using a method of constant shares and allowing for an average serviceable lifetime of 30 years. Finally, due to diversity of haulage equipment, we have homogenised, it based on energy performance, average traction power and productive routes. Thus, each unit of capital would represent a machine with the same energy performance, average traction power and productive routes as an electric locomotive in 1980 . In doing this, the intention is to capture the modemisation process experienced by motor equipment over the period studied.

With regard to the total capital cost, we have used investments made by RENFE in mobile equipment, divided by the average number of years of serviceable life of said equipment material, plus the expenses in repayments, all in millions of current pesetas.

As it would also be desirable to incorporate a variable which could capture the modemisation process on the railway network structure, we have taken traffic density (MODER) as a proxy of efforts made to improve the quality of the network. However, given the complexity of railway transport technology, it would be naive to think that in a distance function estimation we could encompass all the elements that could affect it.

Finally, we have incorporated another time trend variable (PROGC) from 1984 with the idea of capturing the influence of management contract established in RENFE from this date.

The series of annual data used comes from the Communications and Transport Annual Report, prepared by the Institute of Transport and Communications Studies, RENFE memorandums, Spain's National Accounts and Muñoz Rubio (1995). 


\section{EMPIRICAL RESULTS}

We jointly estimate the system of equations for the input distance function and the share equations given by expressions (18)-(19), imposing homogeneity and symmetry restrictions, for the period 1955-1995.

In accordance with the theoretical model presented in section 2 , the outputs ( $\mathrm{Fkm}$ and $\mathrm{Pkm}$ ) would be exogenous and the inputs (E, $\mathrm{L}$ and $\mathrm{K}$ ) endogenous. As a result of this, in equations (18)-(19), we have the problem that the inputs and the errors are correlated. ${ }^{10}$ To resolve this, the system has been estimated using instrumental variables. As instruments, the following Spanish macro measures have been used: fixed capital, number of employees in the agricultural sector and consumption of automobile gasoline.

Moreover, the theoretical model captures the idea that allocative inefficiency can be systematic and continuous in time. In contrast to Grosskopf and Hayes (1993) this fact is taken into account in our estimation. For this reason, in the error term $\mu_{i}$ of the share equations we consider two components with distinct characteristics. We assume that the error term has an additive structure of the form:

$$
\mu_{i}=\eta_{i}+A_{i} \quad i=1, \ldots, n
$$

\footnotetext{
${ }^{10}$ For a discussion on this point, see Coelli and Perelman (1996) and Akinson et al. (1998).
} 
$\eta_{i}$ being a random disturbance term with the usual characteristics (iid, $N\left(0, \sigma^{2}\right)$ ) which captures random factors and $A_{i}$ representing the deviation (positive or negative) of the observed proportion of expenditure with respect to the optimum. This deviation could arise from the systematic utilisation of the input in a proportion different from that which would minimise costs. We assume therefore that $A_{i}$ is a variable which is iid with mean $a_{i}$ and variance $\sigma_{a_{i}}^{2}$. That is, $a_{i}$ indicates the average value of the cost of absolute allocative inefficiency. Thus, equation (19) should be rewritten as

$$
\frac{x_{i} w_{i}}{C}=\left(\beta_{i}+a_{i}\right)+\sum_{j=1}^{n} \beta_{i j} \ln x_{j}+\sum_{r=1}^{m} \rho_{r i} \ln y_{r}+\left(A_{i}-a_{j}\right)+\eta_{i}
$$

where the new error has mean zero.

The relative allocative inefficiency is given by the expression $k_{i j}$ (see equation 22) and is obtained from the parameters estimated from the system of equations. It is important to point out that if we did not take into account the correction of the error term proposed in equation (19') and the $a_{1}$ parameters were significantly different from zero, the $k_{i j}$ coefficients would be biased; moreover, at the sample mean the $k_{i j}$ values would not be significantly different from one.

The estimation of the system (18)-(19') has been carried out by means of iterative seemingly unrelated regressions (ITSUR), which is equivalent to maximum likelihood estimation and invariant to the omitted share equation.

Before commenting on the results, two final considerations should be made. Firstly, we take into account that the errors of the system (18)-(19') display first-order autocorrelation. A first-order autoregressive parameter has therefore been introduced 
into the distance function and the cost share equations. Following Friendlaender et al. (1993) and Berndt et al (1993), the coefficient of the autoregressive term has been fixed at the same value across the different share equations in order to maintain the property that the model be invariant to the elimination of any share equation. Secondly, attention should be drawn to the fact that the variables are in the form of deviations with respect to their geometric means. That is, the first-order coefficients of the distance function can be interpreted as elasticities at the sample mean."

The parameters obtained from the estimation of the system (18)-(19') are presented in Table 1. It is verified that the distance function, at the sample mean, fulfils the properties of being increasing and concave in inputs and decreasing in outputs (see section 3.1), and is also homothetic. ${ }^{12}$ Moreover, the results show the greater weight that the passenger output has over freight in the distance function, as well as the greater weight that the labour input has over the other inputs. Also, the dummy variable which captures the introduction of the management contracts (PROGC) turns out to be significant and to have a negative sign, reflecting a reduction in the inputs, ceteris paribus. On the other hand, the coefficient of the variable which measures the process of modernisation of the network is positive and significant. This positive sign indicates that if in the presence of technological progress the firm maintains the same combination of inputs to produce a given quantity of output, the distance value will increase. $^{13}$

The estimated parameters $a_{L}, a_{K}$ and $a_{E}$ show, as we have mentioned, the average

\footnotetext{
${ }^{11}$ Except for the dummy yariables which are not expressed in logs.

${ }^{12}$ Homotheticity requires that $\rho_{r i}=0, \forall r, i$. The test statistic has a value of 4.69 and given that it has a $\chi^{2}$ with 4 degrees of freedom, we cannot reject the hypothesis of homotheticity.

${ }^{13}$ Graphically, in Figure 1, taking $P$ as our point of reference a technological improvement will lead to a shift of the isoquant to the left. See Fare and Grosskopf (1995) to construct a test of technical change.
} 
cost of absolute allocative inefficiency of the factors labour, capital and energy respectively. The results show that $a_{L}$ and $a_{K}$ are significantly different from zero which implies that, at the sample mean, labour and capital have been employed inefficiently. In absolute terms, labour has been used in a quantity greater than the optimum while capital has been underutilized. The parameter $a_{E}$ has been restricted to zero because in a earlier estimation its value was found not to be significantly different from zero. ${ }^{14}$.

From the system $(18)-\left(19^{\prime}\right)$ we have calculate the mean values and evolution over time of the allocative inefficiency, in relative terms, in accordance with what has been set out in section four. Moreover, from the estimated parameters we could only obtain a single value of $k_{i j}$ for each observation. In order to get a distribution for these $k_{i j}$, we have used a standard bootstrap technique, consisting of selecting a random sample of residuals from the estimation of the system (18)-(19'). Subsequently, "new" dependent variables were generated for each of the equations of the system, equal to the residuals selected randomly plus the value of the prediction of the corresponding equations. The reestimation of the system $(18)-\left(19^{\prime}\right)$ with the pseudodata generated in this manner was repeated 100 times. ${ }^{15}$ To obtain the confidence intervals for the $k_{i j}$ we used the percentile method (Efron and Tibshirani, 1986).

Table 2 shows the results for the proportionality factors evaluated at the sample mean, together with their confidence intervals. Values of $k_{i j}$ less than one indicate, given the factor prices, that input $i$ is being overutilised with respect to input $j$ and vice versa.

\footnotetext{
${ }^{14}$ The estimated $a_{E}$ was 0.01 with a t-statistic of 0.24 .

${ }^{15}$ Taking into account in each case the correction for autocorrelation.
} 
The results show that the capital and energy inputs are being relatively underutilised with respect to labour $\left(k_{L A B O U R, E N E R G Y}=0.82\right.$ and $\left.k_{L A B O U R, C A P I T A L}=0.39\right)$. Moreover, energy is overutilised with respect to capital $\left(k_{\text {ENERGY, CAPITAL }}=0.71\right)$.

Figure 3 illustrates the evolution over time of these coefficients. It can be observed that the values of $k_{L A B O U R, C A P I T A L}$ are below one during the period analysed, implying that the relative overutilisation of labour with respect to capital has been maintained over the 41 years studied. Certain parallels are also revealed in the behaviour of $k_{L A B O U R, C A P T T A L}$ and $K_{E N E R G Y, C A P T A L}$ : allocative inefficiency has tended to be corrected over the period 1963-73. In this period RENFE experienced the highest levels of capital investment in its history due to the Plan Decenal de Modernización (TenYear Modernization Plan). An improvement can also be appreciated as a consequence of the introduction of the management contracts in 1984.

With regard to the evolution over time of the coefficient $k_{L A B O U R \text {, ENERGY, we can }}$ see that over the earlier years of the period studied there was an overutilisation of energy, with the opposite occurring from 1966 on, i.e. the overutilisation of labour with respect to energy, a situation gradually accentuated over the remainder of the period.

Moreover, as a byproduct of the analysis, we have measured of returns to scale in RENFE. Its mean value turns out to be 1.37 , which is consistent with the majority of the values presented in the literature on rail transport. ${ }^{16}$

\footnotetext{
${ }^{16}$ The retums to scale associated with an increase in outputs is defined as: $R S T=-\frac{1}{\partial D_{l}}$ where y is
} the vector of outputs. 


\section{SUMMARY AND CONCLUSIONS}

This paper is an empirical application of the distance function to study the allocative efficiency of a regulated railway firm, RENFE, where the cost minimising hypothesis may be questioned. The distance function, which is the dual of the cost function, completely describes the technology and, like the cost function, it allowis a multiproduct analysis. However, unlike the cost function, the input prices are not needed for its calculation and it does not imply cost minimisation.

By means of this technique we have obtained the shadow prices of the productive factors, which satisfy the condition of minimum cost. These shadow prices are used to calculate the degree of allocative inefficiency of the firm and the origin of this inefficiency by using a parametric correction of prices $\left(k_{i j}\right)$. The procedure followed has consisted of estimating a system of equations for the input distance function and cost share equations, employing the iterative seemingly unrelated regressions method (ITSUR). Moreover, in contrast with other studies which have used this method, we assume that the employment of an input in a proportion different from that which would minimise cost could be systematic, and incorporate this possibility into our empirical model. The model was estimated using annual data over the period 1955-95. In order to achieve a distribution and the confidence intervals of the proportionality terms estimated, $k_{i j}$, we have used a standard bootstrap technique.

The results of this study indicate that there is no allocative efficiency, since the calculated shadow prices are different to those of the market. To be precise, we have observed an overutilisation of labour relative to capital and energy. 
This overutilisation could be due in a some way to the difficulty of adjusting the optimal labour quantity in a regulated environment such as that in which RENFE operates. Moreover, and in accordance with our theoretical model, we also consider that the overutilisation of labour has been due in part to the lack of incentives at managerial to achieve cost minimisation. 
TABLE 1

Distance Function Estimated

(sample 1955-1995)

\begin{tabular}{|c|c|c|}
\hline Variable & Coefficient & t-statistic \\
\hline Constant & 1.9324 & 1.1134 \\
\hline $\log (F k m)$ & -0.4001 & -6.8821 \\
\hline $\log (\mathrm{Pkm})$ & -0.9624 & -9.3511 \\
\hline $\log (\mathrm{L})$ & 0.6262 & 18.9441 \\
\hline $\log (E)$ & 0.0950 & 5.2396 \\
\hline $\log (K)$ & 0.2786 & 8.4083 \\
\hline $\log (F k m) \cdot \log (F k m)$ & -4.0454 & -1.9820 \\
\hline $\log (P k m) \cdot \log (P k m)$ & 5.3174 & 3.0681 \\
\hline $\log (F k m) \cdot \log (P k m)$ & -0.9593 & -0.7645 \\
\hline $\log (L) \cdot \log (L)$ & 0.0141 & 0.3619 \\
\hline $\log (\mathrm{L}) \cdot \log (\mathrm{K})$ & 0.0198 & 0.7413 \\
\hline $\log (L) \cdot \log (E)$ & -0.0339 & -1.6192 \\
\hline $\log (E) \cdot \log (K)$ & -0.0111 & -0.7286 \\
\hline $\log (E) \cdot \log (E)$ & 0.0451 & 2.6332 \\
\hline $\log (K) \cdot \log (K)$ & -0.0086 & -0.3527 \\
\hline $\log (\mathrm{Fkm}) \cdot \log (\mathrm{L})$ & 0.0676 & 1.2265 \\
\hline $\log (\mathrm{Fkm}) \cdot \log (\mathrm{K})$ & 0.0178 & 0.4183 \\
\hline $\log (F k m) \cdot \log (E)$ & -0.0855 & -1.9253 \\
\hline $\log (P k m) \cdot \log (\mathrm{L})$ & -0.0075 & -0.1274 \\
\hline $\log (P k m) \cdot \log (E)$ & -0.0410 & -0.8223 \\
\hline $\log (P k m) \cdot \log (K)$ & 0.0485 & 1.0462 \\
\hline $\log (\mathrm{Pkm}) \cdot \mathrm{PROGC}$ & 0.0158 & 0.6840 \\
\hline $\log (\mathrm{Fkm}) \cdot$ PROGC & -0.0087 & -0.2344 \\
\hline PROGC·PROGC & -0.0001 & -0.1484 \\
\hline PROGC & -0.0229 & -2.9255 \\
\hline $\log (E) \cdot P R O G C$ & -0.0018 & -0.6578 \\
\hline $\log (L) \cdot P R O G C$ & -0.0135 & -3.4299 \\
\hline $\log (\mathrm{K}) \cdot \mathrm{PROGC}$ & 0.0154 & 5.0068 \\
\hline PROGC $\cdot$ MODER & -0.0123 & -0.3957 \\
\hline MODER & 0.9065 & 9.1480 \\
\hline MODER $\cdot$ MODER & 0.2542 & 0.1318 \\
\hline MODER $\cdot \log (\mathrm{Pkm})$ & -2.5724 & -1.5142 \\
\hline MODER $\cdot \log (\mathrm{Fkm})$ & 1.6300 & 0.8752 \\
\hline MODER $\cdot \log (L)$ & -0.0667 & -1.0293 \\
\hline MODER $\cdot \operatorname{LOg}(K)$ & -0.0383 & -0.7593 \\
\hline MODER $\cdot \log (E)$ & 0.1051 & 1.9283 \\
\hline$a_{L}$ & 0.1371 & 3.4059 \\
\hline$a_{k}$ & -0.1371 & -3.4059 \\
\hline
\end{tabular}


TABLE 1 (cont.)

Statistics of Model

\begin{tabular}{cccc}
\hline Equation & R-squared & DW & S.E. regression \\
\hline Distance function & -- & 1.98 & 0.016 \\
Labour cost share & 0.97 & 2.09 & 0.017 \\
Capital cost share & 0.96 & 1.70 & 0.013 \\
Energy cost share & 0.99 & 2.15 & 0.015 \\
\hline
\end{tabular}

TABLE 2

PROPORTIONALITY FACTORS

$\mathrm{K}_{\mathrm{ij}}$ VALUES

\section{Average value(*)}

KENERGY, CAPTAL

0.7142

$(0.61,0.81)$

K LABOUR.CAPTtal

0.3877

$(0.32,0.47)$

K LABOUR ENERGY

0.8242

$(0.75,0.88)$

$\left(^{*}\right)$ Evaluated at the means of the data using parameter estimates of (18)-(19'). Note: confidence intervals at $95 \%$ of $k_{i j}$ figures are in parentheses. 

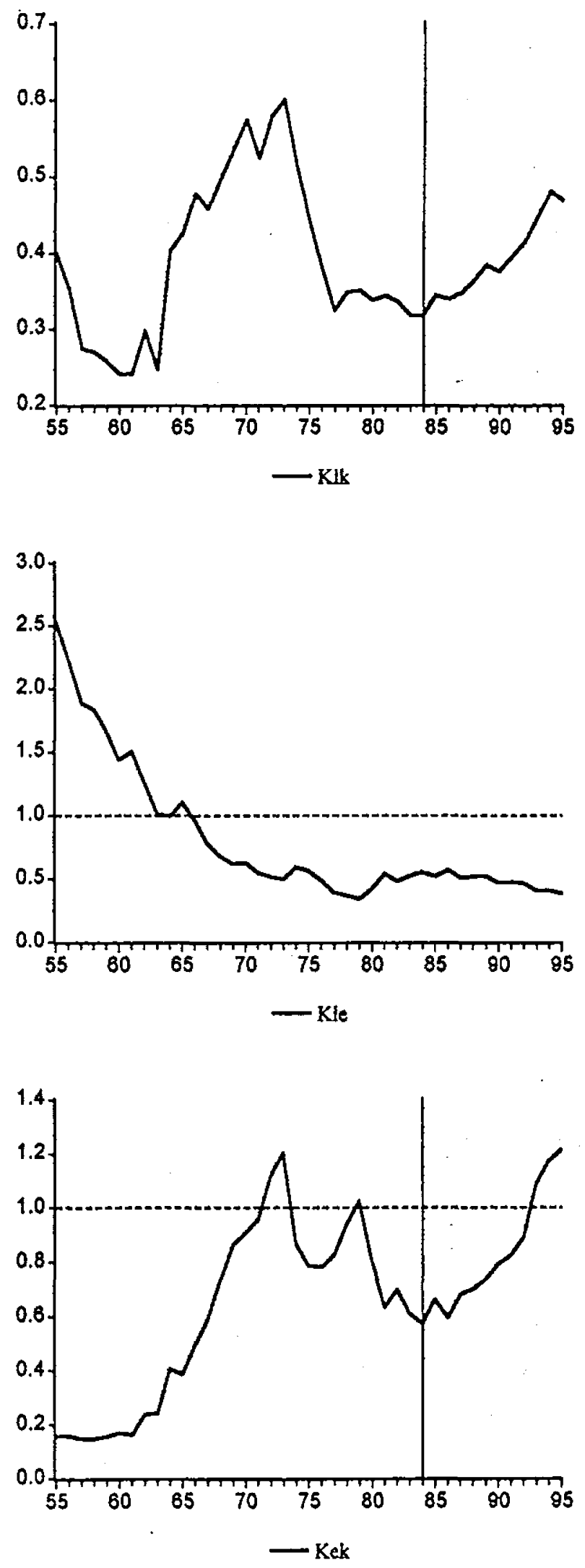

FIGURE 3

Time path of the coefficient $k_{i j}$ 


\section{References}

Atkinson, S. and Halvorsen, R., 1986. The relative efficiency of public and private firms in a regulated environment: the case of U.S. electric utilities, Journal of Public Economics, 29, pp. 281-94.

Atkinson, S., Färe, R. and Primont, D., 1998. Stochastic estimation of firm inefficiency using distance functions. ", mimeo, Department of Economics, University of Georgia.

Blackorby, C. and Russel, R.R.; 1989. Will the real elasticity of substitution please stand up? (A comparison of the Allen/Uzawa and Morishima Elasticities), American Economic Review, 79, pp. 882-888.

Berndt, E., Friedlaender, A, Chiang, J., Showalter, M. and Vellturo, C.; 1993. Mergers, deregulation and cost savings in the US rail industry, Journal of Productivity Analysis, 4 (1-2), pp. 127-144.

Bosco, B., 1996. Excess-input expenditure estimated by means of an input-distance function: the case of public railways, Applied Economics, 28, pp. 491-497.

Carbajo, J. C. and De Rus, G., 1991. Railway Transport Policy in Spain, Journal of Transport Economics and Policy, vol. XXV (2), pp. 209-215.

Coelli, T. and Perelman, S.; 1996. Efficiency measurement, multiple-output technologies and distance functions with application to European railways, mimeo, CREEPP, Université of Liège.

Comes, R.; 1992. Duality and modern economics, Cambridge University Press, Cambridge.

De Rus, G.; 1989. Las empresas públicas de transporte en España, Papeles de Economía Española, 38, pp. 349-382.

Domenech, R., 1993. Funciones de costes para la banca española: un análisis con datos de panel, Investigaciones Económicas, vol. XVII, pp. 263-284.

Eakin, B.K. and Kniesner, T. J., 1988. Estimating a non-minimum cost function for hospitals, Southem Economic Journal, 54, pp. 583-597.

Efron, B. and Tibshirani, R., 1986. Bootstrap methods for standard errors, confidence intervals, and other measures of statistical accuracy, Statistical Science, 1, pp. 54-77.

English, M., Grosskopf, S., Hayes, K. and Yaisawarng, S., 1993. Output allocative and technical efficiency of banks, Journal of Banking and Finance, 17, pp. 349-366.

Färe, R. and Grosskopf, S., 1990. A distance function approach to price efficiency, Journal of Public Economics, 43, pp. 123-126.

Färe, R. and Grosskopf, S., 1995. Nonparametric tests of regularity, Farreil efficiency, and goodness-of-fit, Joumal of Econometrics, 69, pp. 415-425.

Färe, R. and Primont, D., 1995. Multi-output production and duality: theory and applications, Kluwer Academic Publishers, Norwell.

Farrell, M. J., 1957. The measurement of productive efficiency, Journal of The Royal Statistical Society", Serie A, 120, pp. 253-281.

Friedlaender, A. F., Berndt, E. R., Shaw-Er Wang Chiang, J., Showlater, M. and Vellturo, C. A., 1993. Rail cost and capital adjustments in a quasi-regulated 
environment, Journal of Transport Economics and Policy, vol. XXVII (1), pp. 131-152.

Gathon, H.-J. and Pestieau, P.; 1992. Measuring technical efficiency in european railways: a panel data approach, The Journal of Productivity Analysis, 3, pp. 131-151.

Gathon, H-J. and Pestieau, P., 1995. Decomposing efficiency into its managerial and its regulatory components: the case of European railways, European Journal of Operational Research, 80, pp. 500-507.

Greene, W. H., 1980. Maximum likelihood estimation of econometric frontier functions, Joumal of Econometrics, 13, pp. 27-53.

Grosskopf, S. and Hayes, K., 1993. Local public sector bureaucrats and their input choices, Journal of Urban Economics, 33, pp. 151-166.

Grosskopf, S., Hayes, K. and Hirschberg, J., 1995. Fiscal stress and the production of public safety: a distance function approach, Journal of Public Economics, 57, pp. 277. 296.

Grosskopf, S., Margaritis, D. and Valdmanis, V., 1995. Estimating output substitutability of hospital services: A distance function approach, European Journal of Operational Research, 80, pp. 575-586.

INE, Contabilidad Nacional de España (Spain National Accounts). Several issues.

Jacobsen, S. E., 1972. On Shephard's duality theorem, Journal of Economic Theory, 4, pp. $458-464$.

McGeehan, H., 1993. Railway costs and productivity growth, Joumal of Transport Economics and Policy, vol. XXVI (2), pp. 19.32.

Memorias de RENFE. Various issues.

Ministerio de Transportes. Informes anuales. Various issues.

Muñoz Rubio, M., 1995. Renfe(1941-1991). Medio Siglo de Ferrocarril Público, Ediciones Luna, Madrid.

Niskanen, W.A., 1968. The peculiar economics of bureaucracy, American Economic Review, 58, pp. 293-305.

Perelman, S. and Pestieau, P., 1988. Technical Performance in Public Enterprises: a comparative study of Railways and postal services, European Economic Review, 32, pp. 432.441 .

Shephard, R.W., 1953. Cost and Production Functions, Princeton University Press, Princenton.

Toda, Y., 1976.Estimation of a cost function when the cost is not minimum: the case of soviet manufacturing industries, 1958-1971, The Review of Economics and Statistics", 58 , pp. $259-268$.

Williamson, O., 1963. Managerial discretion and business behaviour, American Economic Review, 5, pp. 1032-1057. 


\section{FACULTAD DE CIENCIAS ECONÓMICAS Y EMPRESARIALES RELACIÓN DE DOCUMENTOS DE TRABAJO:}

Doc. $001 / 88$
Doc. $002 / 88$
Doc. $003 / 88$
Doc. $004 / 88$
Doc. $005 / 89$
Doc. $006 / 89$
Doc. $007 / 89$
Doc. $008 / 89$
Doc. $009 / 89$
Doc. $010 / 90$
Doc. $011 / 90$
Doc. $012 / 90$

Doc. 013/90

Doc. 014/90

Doc. $015 / 90$

Doc. $016 / 90$

Doc. $017 / 90$

Doc. $018 / 90$

Doc. $019 / 90$

Doc. $020 / 90$

Doc. $021 / 90$

Doc. $022 / 90$

Doc. $023 / 90$
JUAN A. VAZQUEZ GARCIA. - Las intervenciones estatales en la minería del carbón.

CARLOS MONASTERIO ESCUDERO. - Una valoración crítica del nuevo sistema de financiación autonómica.

ANA ISABEL FERNANDEZ ALVAREZ; RAFAEL GARCIA RODRIGUEZ; JUAN VENTURA VICTORIA. - Análisis del crecimiento sostenible por los distintos sectores empresariales.

JAVIER SUAREZ PANDIELIO.- Una propuesta para la integración multijurisdiccional.

LUIS JULIO TASCON FERNANDEZ; JOSE MANUEL DIEZ MODINO.- La modernización del sector agrario en la provincia de León.

JOSE MANUEL PRADO LORENZO.- El principio de gestión continuada: Evolución e implicaciones.

JAVIER SUAREZ PANDIELLO. - El gasto público del Ayuntamiento de Oviedo $(1982-88)$.

EEIIX IOBO ALEU. - El gasto público en productos industriales para la salud.

FEIIX IOBO ALED. - La evolución de las patentes sobre medicamentos en los paises desarrollados.

RODOLFO VAzQUEZ CASTELLES. - Investigación de las preferencias del cosnumidor mediante análisis de conjunto.

ANTONIO APARICIO PEREZ. - Infracciones y sanciones en materia tributaria.

MONTSERRAT DIAZ FERNANDEZ; CONCBPCION GONZATEZ VEIGA.- Una aproximación metodológica al estudio de las matemáticas aplicadas a la economía.

EQUIPO MECO. - Medidas de desigualdad: un estudio analítico

JAVIER SUAREZ PANDIELLO. - Una estimación de las necesidades de gastos para los municipios de menor dimensión.

ANTONIO MARTINEZ ARIAS.- Auditoría de la información financiera.

MONTSHRRAT DIAZ FERNANDEZ.- La población como variable endógena

JAVIER SUAREZ PANDIELIO. - La redistribución local en los paises de nuestro entorno.

RODOLFO GUTIERREZ PALACIOS; JOSE MARIA GARCIA BLANCO. - "LOS aspectos invisibles" del declive económico: el caso de Asturias.

RODOLFO VAZQUEZ CASIELLES; JOAN TRESPALACIOS GUTIERREZ. - LA política de precios en los establecimientos detallistas.

CANDIDO PANEDA FBRNANDEZ, - La demarcación de la economía (seguida de un apéndice sobre su relación con la Estructura Económica).

JOAOUIN LORENCES. - Margen precio-coste variable medio y poder de monopolio.

MANUEL LAFUENTE ROBLIDO; ISIDRO SANCHEZ ALVAREZ. - El T.A.E. de las operaciones bancarias.

ISIDRO SANCHEZ ALVAREZ. - Amortización y coste de préstamos con hojas de cálculo. 
Doc. $024 / 90$

DoC. $025 / 90$

Doc. $026 / 91$

DoC. $027 / 91$

Doc. $028 / 91$

Doc. $029 / 91$

Doc. $030 / 91$

Doc. $031 / 91$

Doc. $032 / 91$

Doc. 033/91

DoC. $034 / 91$

Doc. $035 / 91$

Doc. $036 / 91$

Doc. 037/91

Doc. $038 / 91$

Doc. $039 / 92$

Doc. $040 / 92$

Doc. $041 / 92$

Doc. 042/92

Doc. $043 / 92$

Doc. $044 / 92$

Doc. $045 / 92$

Doc. $046 / 92$

Doc. $047 / 92$
LUIS JULIO TASCON FERNANDEZ; JEAN-MARC BUIGUES. - Un ejemplo de política municipal: precios $y$.salarios en la ciudad de teón (1613 1813).

MYRIAM GARCIA OLALLA. - Utilidad de la teorías de las opciones para la administración financiera de la empresa.

JOAQUIN GARCIA MORCIA.- Novedades de la legislación laboral (octubre 1990 - enero 1991)

CANDIDO PAÑED.- Agricultura familiar y mantenimiento del empleo: el caso de Asturias.

PILAR SAENZ DE JUBBRA.- La fiscalidad de planes $y$ fondos de pensiones.

ESTEBAN FERNANDEZ SANCHEZ,- La cooperación emoresarial: concepto y tipología (*)

JOAQOIN IORENCES. - Características de la población parada en el mercado de trabajo asturiano.

JOAQUIN LORENCES. - Caracteristicas de la población activa en Asturias.

CARMEN BENAVIDES GONZATEZ. - Politica económica regional

BENITO ARRUÑADA SANCHDZ. - La conversión coactiva de acciones comunes en acciones sin voto para lograr el control de las sociedades anónimas: De cómo la ingenuidad legal prefigura el fraude.

BENITO ARRUNADA SANCHEZ.- Restricciones institucionales $y$ posibilidades estratégicas.

NURIA BOSCH; JAVIRR SUAREZ PANDIELIO,- Seven Hypotheses About Public Chjoice and Local Spending. (A test for Spanish municipalities).

CARMEN EZRNANDEZ CUERVO; LOIS JULIO TASCON FERNANDEZ. - De una olvidada revisión critica sobre algunas fuentes históricoeconómicas: las ordenanzas de la gobernación de la cabrera.

ANA JESUS IOPEZ; RIGOBERTO PEREZ SUAREZ. - Indicadores de desigualdad $y$ pobreza. Nuevas alternativas.

JUAN A. VAZQUEZ GARCIA; MANUEL HJRNANDEZ MOÑIZ. - La industria asturiana: ¿Podemos pasar la página del declive?.

INES RUBIN FERNANDEZ. - La Contabilidad de la Empresa y la Contabilidad Nacional.

ESTIBAN GARCIA CANAL. - La Cooperación interempresarial en España: Características de los acuerdos de cooperación suscritos entre 1986 y 1989.

ESTEBAN GARCIA CANAL.- Tendencias empiricas en la conclusión de acuerdos de cooperación.

JOAOUIN GARCIA MURCIA.- NOvedades en la Legislación Laboral. RODOLFO VAZQUEZ CASIELLES. - El comportamiento del consumidor y la estrategia de distribución comercial: Una aplicación empirica al mercado de Asturias.

CAMILO JOSE VAZQUEZ ORDAS.- Un marco teórico para el estudio de las fusiones empresariales.

CAMITO JOSE VAZOUEZ ORDAS.- Creación de valor en las fusiones empresariales a través de un mayor poder de mercado.

ISIDRO SANCHIZ ALVAREZ. - Influencia relativa de la evolución demográfica en le futuro aumento del gasto en pensiones de jubilación.

ISIDRO SANCHEZ ALVAREZ.- Aspectos demográficos del sistema de pensiones de jubilación español.

pag. 2 
DoC. $048 / 92$

Doc. $049 / 92$

DoC. $050 / 92$

Doc. $051 / 92$

Doc. $052 / 92$

Doc. $053 / 92$

Doc. 054/92

Doc. $055 / 92$

Doc. $056 / 92$

Doc. $057 / 92$

Doc. $058 / 92$

Doc. 059/92

DoC. 060/94

DoC. $061 / 94$

Doc. 062/94

DoC. $063 / 94$

Doc. $064 / 94$

DoC. $065 / 94$

Doc. $066 / 94$

Doc. 067/94

Doc. $068 / 94$

Doc. $069 / 94$

SUSANA LOREZ ARES.- Marketing telefónico: concepto $y$ aplicaciones.

CESAR RODRIGUEZ GUTIBRREZ.- Las influencias familiares en el desempleo juvenil.

CESAR RODRIGUEZ GOTIERREZ. - La adquisición de capital humano: un modelo teórico y su contrastación.

MARTA IBANEZ PASCOAI.- El orígen social y. la inserción laboral.

JUAN TRESPAIACIOS GUTIERREZ.- Estudio del sector comercial en la ciudad de Oviedo.

JOLITA GARCIA DIEZ.- Auditoría de cuentas: su regulación en la CEE y en España. Una evidencia de su importancia.

SUSANA MENENDEZ REQUEJO.- El riesgo de los sectores empresariales españoles: rendimiento requerido por los inversores.

CARMEN BENAVIDES GONZALEZ.- Una valoración económica de la obtención de productos derivados del petroleo a partir del carbón

IGNACIO ALFREDO RODRIGUEZ-DEL BOSQUE RODRIGUEZ. - COnSECUENCIAS sobre el consumidor de las actuaciones bancarias ante el nuevo entorno competitivo.

LAURA CABIEDES MIRAGAYA.- Relación entre la teoría del comercio internacional y los estudios de organización industrial.

JOSE LOIS GARCIA SOAREZ.- LOS principios contables en un entorno de regulación.

$M$ JESUS RIO FRRNANDEZ; RIGOBERTO PEREZ SUAREZ.-

Cuantificación de la concentración industrial: un enfoque analitico.

Ma JOSE FERNANDEZ ANTUNA.- Regulación y politica comunitaria en materia de transportes.

CESAR RODRIGUEZ GUTIERREZ.- Factores determinantes de la afiliación sindical en España.

VICTOR FERNANDEZ BLANCO.- Determinantes de la localización de las empresas industriales en España: nuevos resultados.

ESTEBAN GARCIA CANAL. - La crisis de la estructura multidivisional.

MONTSERRAT DIAZ FERNANDEZ; EMILIO COSTA RERARAZ,- Metodología de la investigación econométrica.

MONTSERRAT DIAZ FERNANDEZ; EMILIO COSTA REPARAZ.- Análisis Cualitativo de la fecundidad y participación femenina en el mercado de trabajo.

JOAQUIN GARCIA MURCIA. - La supervision colectiva de los actos de contratación: la Ley $2 / 1991$ de información a los representantes de los trabajadores.

JOSE LUIS GARCIA LAPRESTA; Me VICTORIA RODRIGUEZ URIA.Coherencia en preferencias difusas.

VICTOR FERNANDEZ; JOAQUIN LORENCES; CESAR RODRIGUEZ.Diferencias interterritoriales de salarios $y$ negociacion colectiva en España.

Ma DEL MAR ARENAS PARRA; Ma VICTORIA RODRÍGUEZ URÍA.

- Programación clásica y teoría del consumidor. 
Doc. $070 / 94$

Doc. $071 / 94$

Doc. $072 / 94$

Doc. $073 / 94$

Doc. $074 / 94$

Doc. $075 / 94$

Doc. $076 / 94$

Doc. $077 / 94$

Doc. $078 / 94$

Doc. $079 / 94$

DoC. $080 / 94$

Doc. $081 / 94$

Doc. $082 / 95$

DC. . $083 / 95$

DoC. $084 / 95$

Doc. $085 / 95$

Doc. $086 / 95$

Doc. $087 / 95$

DoC. $088 / 95$

Doc. $089 / 95$

Doc. 090/95

Doc. $091 / 95$

Doc. 092/95
$M$ DE LOS ÁNGELES MENÉNDEZ DE LA OZ; Ma VICTORTA RODRÍGUEZ URÍA. - Tantos efectivos en los empréstitos. AMELIA BILBAO TEROL; CONCEPCIÓN GONZÁLEZ VEIGA; MA VICTORIA RODRÍGUEZ URIA.- Matrices especiales. Aplicacioneseconómicas. RODOLFO GUTIERREZ. - La representación sindical: Resultados electorales $Y$ actitudes hacia sindicatos.

VÍCTOR FERNÁNDEZ BLANCO.- ECONOMías de aglomeración y localización de las empresas industriales en España.

JOAQUÍN LORENCES RODRÍGUEZ; FLORENTINO FELGUEROSO FERNÁNDEZ.Salarios pactados en los convenios provinciales $y$ salarios percibidos.

ESTEBAN FERNÁNDEZ SÁNCHEZ; CAMTLO JOSÉ VÁZQUEZ ORDÁS.- La internacionalización de la empresa.

SANTIAGO R. MARTÍNEZ ARGǗLLES.- Análisis de los efectos regionales de la terciarización de ramas industriales a través de tablas input-output. El caso de la economía asturiana.

VÍCTOR IGLESIAS ARGÜ̈LLES. - Tipos de variables y metodología a emplear en la identificación de los grupos estratégicos. Una aplicación empirica al sector detallista en Asturias.

MARTA IBÁÑEZ PASCOAL; $F$. JAVIER MATO DÍ́Z.- La formación no reglada a examen. Hacia un perfil de sus usuarios.

IGNACIO A. RODRIGUEZ-DEL BOSQUE RODRÍGUEZ.- Planificación $Y$ organización de la fuerza de ventas de la emoresa.

FRANCISCO GONZÁtEZ RODRÍGUEZ.- La reacción del precio de las acciones ante anuncios de cambios en los dividendos.

SUSANA MENÉLDEZ REQUEJO.- Relaciones de dependencia de las decisiones de inversión, financiación $y$ dividendos.

MONTSERRAT DÍAZ FERNÁNDEZ; EMTLIO COSTA REPARAZ; Ma del MAR LIORENTE MARRÓN. - Una aproximación empírica al comportamiento de los precios de la vivienda en España.

Ma CONCGPCIÓN GONZÁLEZ VEIGA; Ma VICTORIA RODRÍGUEZ URÍA.Matrices semipositivas $y$ análisis interindustrial. Aplicaciones al estudio del modelo de sraffa-Leontief.

ESTHBAN GARCÍA CANAL.- La forma contractual en las alianzas domésticas e internacionales.

MARGARTTA ARGÜELLES VÉLEZ; CAFMEN BENAVIDES GONZÁTEZ.- La incidencia de la politica de la competencia comunitaria sobre la cohesión económica y social.

VÍCTOR ELRNÁNDEZ BLANCO. - La demanda de cine en España. 1968-1992.

JUAN PRTETO RODRÍGUEZ. - Discriminación salarial de la mujer $y$ movilidad laboral.

M* CONCMPCIÓN GONZÁLEZ VEIGA.- La teoría del caos.nuevas perspectivas en la modelización económica.

SUSANA IÓRzZ ARES.- Simulación de fenómenos de espera de capacidad limitada con llegadas $y$ número de servidores dependientes del tiempo con hoja de cálculo.

JAVIER MATO DÍZ.- ¿Existe sobrecualificación en España?. Algunas variables explicativas.

$M^{a}$ JOSÉ SANZO PḰRE.- Estrategia de distribución para productos $y$ mercados industriales.

JOSÉ BAÑOS PINO; VÍCTOR EZRNÁNDEZ BLANCO.- Demanda de cine en España: Un análisis de cointegración. 
Doc. $093 / 95$

Doc. 094/95

Doc. $095 / 95$

Doc. $096 / 95$

Doc. 097/95

Doc. $098 / 95$

Doc. $099 / 96$

Doc. $100 / 96$

Doc. $101 / 96$

DoC. $102 / 96$

DoC. $103 / 96$

Doc. $104 / 96$

Doc. $105 / 96$

Doc. $106 / 96$

Doc. $107 / 96$

Doc. $108 / 96$

Doc. $109 / 96$

Doc. $110 / 96$

Doc . $111 / 96$

Doc. $112 / 96$
Ma IETICIA SANTOS VIJANDE.- La politica de marketing en las empresas de alta tecnología.

RODOLFO VÁZQUEZ CASIELLES; IGNACIO RODRIGUEZ-DEL BOSQUE; AGUSTÍN RUÍz VEGA. - Expectativas y percepciones del consumidor sobre la calidad del servicio. Grupos estratégicos y segmentos del mercado para la distribución comercial minorista.

ANA ISABEL FIRRÁNDEZ; SILVIA GÓMEZ ANSÓN.- La adopción de acuerdos estatutarios antiadquisición.. Evidencia en el mercado de capitales español.

ósCAR RODRÍGUEz BUZNEGo.- Partidos, electores y elecciones locales en Asturias. Un análisis del proceso electoral del 28 de Mayo.

ANA Ma DÍAz MARTíN.- Calidad percibida de los servicios turisticos en el ámbito rural.

MANUEL HDRNÁNDEZ MUÑIZ; JAVIER MATO DÍAZ; JAVIER BLANCO GoNzátez. - Evaluating the impact of the European Regional Development Fund: methodology and results in Asturias (19891993).

JUAN PRIETO; Ma JOSÉ SUÁREZ,- ¿De tal palo tal astilla?: Influencia de las características familiares sobre la ocupación.

JUITTA GARCÍA DÍE; RACHEL JUSSARA VIANNA.- Estudio comparativo de Ios principios contables en Brasil y en España. FRANCISCO $J$, DE LA BALLINA BALLINA. - Desarrollo de campañas de promoción de ventas.

ÓSCAR RODRÍGUEZ BUZNEGO. - Una explicación de la ausencia de la Democracia Cristiana en España.

CÁNDIDO PANEDA IERNÁNDEZ. - Estrategias para el desarrollo de Asturias.

SARA Ma ALONSO; BLANCA PÉREZ GLADISH; M" VICTORIA RODRÍGUEZ URÍA. - Problemas de control óptimo con restricciones: Aplicaciones económicas.

ANTONIO ÁLVAREZ PINILLA; MANUEL MENÉNDEZ MENÉNDEZ;RAFAEL ÁLVAREZ CUESTA.- Eficiencia de las cajas de Ahorro españolas. Resultados de una función de beneficio.

FIORDNINO FELGUEROSO.- Industrywide Collective Bargaining, Wages Gains and Black Labour Marketing Spain.

JUAN VENTURA.- La competencia gestionada en sanidad: Un enfoque contractual

MARÍA VICTORTA RODRÍGUEZ URÍA; ELENA CONSUELO HERNÁNDEZ.Elección social. Teorema de Arrow.

SANTIAGO ÁLVAREZ GARCÍA.- Grupos de interés y corrupción política: La búsqueda de rentas en el sector público.

ANA Ma GUILLEN. - La politica de previsión social española en el marco de la Unión Europea.

VÍCTOR MANUEL GONZÁtEZ MÉNDEz. - La valoración por el mercado de capitales español de la financiación bancaria $y$ de las emisiones de obligaciones.

DRA.MARIA VICTORIA RODRIGUEZ URÍA; D. MIGUEL A.LÓPEZ FERNÁNDEZ; DÑA.BLANCA Ma PEREZ GLADISH.- Aplicaciones económicas del Control öptimo. El problema de la maximización de la utilidad individual del consumo. El problema del mantenimiento y momento de venta de una máquina. 
Doc. $113 / 96$

Doc. $114 / 96$

DoC. $115 / 96$

Doc. $116 / 96$

Doc. $117 / 96$

Doc. $118 / 96$

Doc. $119 / 96$

Doc. $120 / 96$

Doc. $121 / 97$

Doc. $122 / 97$

Doc. $123 / 97$

Doc. $124 / 97$

Doc. $125 / 97$

Doc. $126 / 97$

Doc. $127 / 97$

Doc. $128 / 97$

Doc, $129 / 97$

Doc. $130 / 97$

Doc. $131 / 97$

Doc. $132 / 97$
OSCAR RODRÍGUEZ BUZNEGO.- Elecciones autonómicas, sistemas de partidos $y$ Gobierno en Asturias.

RODOLFO VÁZQUEZ CASIELLES; ANA M DIAZ MARTÍN.El conOCImiento de las expectativas de los clientes: una pieza clave de la calidad de servicio en el turismo.

Jolio Tascón. - El modelo de industrialización pesada en España durante el período de entreguerras.-

ISTHBAN FERNÁNDEZ SÁNCHEZ; JOSÉ $M$. MONTES PEÓN; CAMILO $J$. VÁZQUEZ ORDÁs.- Sobre la importancia de los factores determinantes del beneficio: Análisis de las diferencias de resultados inter $e$ intraindustriales.

AGUSTÍN RUÍZ VIGA; VICTOR IGLESIAS ARGÜELLES.- Elección de Establecimientos detallistas y conducta de compra de productos de gran consumo. Una aplicación emoirica mediante modelos logit.

VICTOR EHRNÁNDEZ BLANCO.- Diferencias entre la asistencia al cine nacional $y$ extranjero en España.

RODOLFO VÁZQUEZ CASIELLES; IGNACIO A. RODRIGGUZZ DEL BOSQUE; ANA Ma DÍAz MARTÍN. - Estructura multidimensional de la calidad de servicio en cadenas de supermercados:desarrollo $y$ validación de la escala calsuper.

ANA BELEN DEL RÍO LANZA. - Elementos de medición de marca desde un enfoque de marketing.

TULITA GARCÍA DÍEZ; CRISTIAN MIAZzo. - Análisis Comparativo de la Información contable empresarial en Argentina y España.

MA MAR LLORENTE MARRÓN; D. EMILIO COSTA REPARAZ; Ma MONTSERRAT DIAZ FERNÁNDEZ. - El Marco teórico de la nueva economía de la familia. Principales aportaciones.

SANTIAGO ALVAREZ GARCíA.- El Estado del bienestar. Origenes, Desarrollo y situación actual.

CONSUELO ABELIÁN COLODRón. - La Ganancia salarial esperada como determinante de la decisión individual de emigrar.

ESTHER LAFUENTE ROBLEDO. - La acreditación hospitalaria: MarCo teórico general.

JOSE ANTONIO GARAY GONZÁLIZ.- Problemática contable del reconocimiento del resultado en la empresa constructora.

ESTMBAN FLRNÁNDEZ; JOSE M.MONTES; GUILLERMO PERRZ-BUSTAMANTE; CAMIIO VÁzQUEZ. - Barreras a la imitación de la tecnología. VICTOR IGLESIAS ARGÜELLES; JUAN A. TRESRATACIOS GUTIERREZ; RODOLEO VÁzQUEZ CASIELIES. - LOS resultados alcanzados por las empresas en las relaciones en los canales de distribución. IETICIA SANTOS VIJANDE; RODOLFO VÁZQUEZ CASIELLES.- La innovación en las empresas de alta tecnología: Factores condicionantes dei resultado cumercial.

RODOLFO GUTIBRREZ.- Individualism and collectivism in human resoruce practices: evidence from three case studies.

VICTOR FERNÁNDEZ BLANCO; JUAN PRIETO RODRÍGUEZ.- DeCisioneS individuales $y$ consumo de bienes culturales en España.

SANTIAGO GONZÁLZZ HERNANDO.- Clasificación de productos de consumo $y$ establecimientos detallistas. Análisis empirico de motivaciones $y$ actitudes del consumidor ante la compra de productos de alimentación $y$ droguería. 
Doc. $133 / 97$

Doc. $134 / 97$

Doc. $135 / 97$

Doc. $136 / 97$

Doc. $137 / 97$

Doc. $138 / 97$

Doc. $139 / 97$

DoC. $140 / 97$

DOC. $141 / 97$

DoC. $142 / 97$

Doc. $143 / 97$

DoC. $144 / 97$

Doc. $145 / 97$

Doc. $146 / 97$

Doc. $147 / 98$

Doc. $148 / 98$

Doc. $149 / 98$

Doc. $150 / 98$
VICTOR IGLESTAS ARGÜELLES. - Factores determinantes del poder negociador en los canales de distribución de productos turisticos.

INÉS RUBÍN FERNÁNDEZ.- Información sobre operaciones con derivados en los informes anuales de las entidades de depósito.

ESTHER LAFUENTE ROBLEDO; ISABEL MANZANO PBREZ.- Aplicación de las técnicas DEA al estudio del sector hospitalario en el Principado de Asturias.

VICTOR MANUEL GONZÁLEZ MÉNDEZ; FRANCISCO GONZÁLEZ RODRÍGUEZ.La valoración por el mercado de capitales español de los procedimientos de resolución de insolvencia financiera.

MARIA JOSÉ SANZO PḰREZ.- Razones de utilización de la venta directa, los distribuidores Independientes $y$ los agentes por parte de las empresas químicas españolas.

LOIS OREA. - Descomposición de la eficiencia económica a través de la estimación de un sistema translog de costes: Una aplicación a las cajas de ahorro españolas.

CRISTINA LOPEZ DUARTE; ESTERAN GARCÍA CANAL.- Naturaleza y estructura de propiedad de las inversiones directas en el exterior: Un modelo integrador basado basado en el análisis de costes de transacción.

CRISTINA LOPEZ DUARTE; ESTEBAN GARCÍA CANAL; ANA VALDÉS

LIANEZA. - Tendencias empiricas en las empresas conjuntas internacionales creadas por empresas españolas (1986-1996).

CONSUELO ABELLÁN COLODRÓN; ANA ISABEL FERNÁNDEZ SÁINZ.Relación entre la duración del desempleo y la probabilidad de emigrar.

CÉSAR RODRIGUEZ GUTIÉRREZ; JUAN PRIETO RODRIGUEZ.- LA participación laboral de la mujer $y$ el efecto del trabajador añadido en el caso español.

RODOLFO VÁZQUEZ CASIELLES; ANA MARÍA DIAZ MARTIN; AGUSTÍN V. RUIZ VEGA.- Planificación de las actividades de marketing para empresas de servicios turisticos: la calidad como soporte de la estrategia competitiva.

LUCÍA AVELLA CAMARBRO; ESTEBAN FERNANDEZ SANCHEZ.- Una aproximación a la emoresa industrial española: Principales caracteristicas de fabricación.

ANA SUÁREZ VÁZQUEZ.- Delimitación comercial de un territorio: Importancia de la información proporcionada por los compradores.

CRISTINA LOREZ DUARTE; ESTMBAN GARCÍA CANAL.- La inversión directa realizada por empresas españolas: análisis a la luz de la teoría del ciclo de desarrollo de la inversión directa en el exterior.

ANA BELEN DEL RIO LANZA; VICTOR IGLESIAS ARGUELIES; RODOLFO VAZQUEZ CASIELLES; AGUSTIN RUIZ VEGA. - Metodologías de medición del valor de la marca.

RAFAEL ALVAREZ CUESTA. - La estimación econométrica de fronteras de producción: una revisión de la literatura.

FERNANDO RUBIERA MOROLLO. - Análisis univariante de las series de empleo terciario de las regiones españolas.

JOSE ANTONIO GARAY GONZALEZ.- LOS gastos $y$ los ingresos plurianuales. 
Doc. $151 / 98$

DoC. $152 / 98$

Doc. $153 / 98$

DoC. $154 / 98$

Doc. $155 / 98$

DoC. $156 / 98$

Doc. $157 / 98$

Doc. $158 / 98$

DoC. $159 / 98$

DoC. $160 / 98$

Doc. $161 / 98$

Doc. $162 / 98$

Doc. $163 / 99$

Doc. $164 / 99$

Doc. $165 / 99$

Doc. $166 / 99$

Doc. $167 / 99$

Doc. $168 / 99$

Doc. $169 / 99$
ISABEL GARCIA DE IA IGLESIA. - La elección contable para los gastos de investigación y desarrollo.

LUIS CASTELIANOS VAL; BMILIO COSTA REPARAZ. - Teoría de sistemas $y$ análisis económico: una aproximación metodológica. Ma DEL CARMEN RAMOS CARVAJAL. - Estimación indirecta de coeficientes input-output.

RODOLEO VAZQUEZ CASIELLES; ANA MARIA DIAZ MARTIN; Ma. IIETICIA SANTOS VIJANDE; AGOSTIN V. ROIZ VEGA.- Utilidad del análisis conjunto para establecer la importancia de las estrategias de calidad en servicios turísticos: simulación de escenarios alternativos en emoresas de turismo rural.

SANTIAGO ALVAREZ GARCIA; ANA ISABEL GONZALEZ GONZALEZ. - El proceso de descentralización fiscal en España, especial referencia a la Comunidad Autónoma del principado de Asturias

SANTIAGO ALVAREZ GARCIA. - La tributación de la unidad familiar. Nuevas consideraciones sobre un antiguo problema.

SUSANA IOPEZ ARES; ISIDRO SANCKEZ ALVAREZ.- Condicionantes demográficos de la economía asturiana.

CELINA GONZATEZ MIBRES.- La marca de la distribución: un fenómeno que afecta a distribuidor, fabricante y consumidor.

IGNACIO DEL ROSAL FERNANDEZ. - Análisis de la demanda agregada de electricidad en España con series temoorales: un tratamiento de cointegración:

JESUS ARANGo. - Evolución y perspectivas del sector agrario en Asturias.

JESUS ARANGO. - Cronología de la construcción Europea.

JULITA GARCIA DIEZ; SUSANA GAGO RODRIGUEZ,-Programas de doctorado en contabilidad en las universidad españolas: estudio empirico.

MAR ARENAS PARRA; AMELIA BILBAO TEROL; BLANCA PÉREZ GLADISH; MA VICTORIA RODRÍGUEZ URÍA; EMILIO CERDÁ TENA (Universidad Complutente de Madrid).- Aplicación de la programación compromiso a la gestión de hospitales públicos.

M. DEL CARMBN RAMOS CARVAJAL. - La comarcalización de las Tablas input-output: Una primera aproximación.

LUIS IGNACIO ÁLVAREZ GONZÁLEZ; RODOLFO VÁZQUEZ CASIELLES; MARÍA LETICIA SANTOS VIJANDE; ANA MARÍA DÍAZ MARTÍN.Orientación al mercado como cultura de negocio y conjunto de actuaciones: Un contraste metodológico para organizaciones no lucrativas.

Ma JOSE SANZO PÉREZ. - Funciones de los vendedores industriales de los distribuidores independientes. Una tipología realizada en el sector químico.

Ma BEGOÑA ÁLVAREZ ÁLVAREZ; RODOLFO VÁZQUEZ CASIELLES; FRANCISCO $J$. DE LA BALLINA BALLINA; $M^{2}$ LETICIA SANTOS VIJANDE.- Evidencias empíricas de la promoción de ventas en los establecimientos detallistas.

BEGOÑA GONZÁtEZ-BUSTO MÚGICA. - La dinámica de sistemas como metodología para la elaboración de modelos de simulación. BEGOÑA GONZÁLEZ-BUSTO MÚGICA.- Reflexiones teóricas sobre el personal sanitario en el Sistema Nacional de Salud Español. 
Doc. $170 / 99$

Doc. $171 / 99$

Doc. $172 / 99$

Doc. $173 / 99$

Doc. $174 / 99$

Doc. $175 / 99$

Doc. $176 / 99$

Doc. $177 / 99$

Doc. $178 / 99$

Doc. $179 / 99$

Doc. $180 / 99$

Doc. $181 / 99$

Doc. $182 / 99$

Doc. $183 / 99$

Doc. $184 / 99$

Doc. $185 / 99$

Doc. $186 / 99$

Doc. $187 / 99$

Doc. $188 / 99$ yolanda álvarez castaño, - Cómo alcanzar el éxito en el proceso de innovación tecnológica.

YOLANDA Álvarez CASTAÑo.- La organización del proceso de desarrollo de un nuevo producto.

RODOLFO VÁZQUEZ CASIELLES; MARÍA LETICIA SANTOS VIJANDE; ANA MARÍA DÍAZ MARTÍN; IUIS IGNACIO ÁLVAREZ GONZÁLEZ.Estrategias de marketing: Desarrollo de investigaciones sobre orientación al mercado y marketing de relaciones.

SANTIAGO R. MARTÍNEZ ARGÜELLES; FERNANDO RUBIERA MOROLLÓN. Patrones de convergencia regional en los servicios de la Economía Española.

JUAN PRIETO RODRÍGUEZ; VÍCTOR FERNÁNDEZ BLANCO. - Are modern and classical music listeners the same people?

VÍCTOR MANUEL GONZÁLEZ MÉNDEZ; FRANCISCO GONZÁLEZ RODRÍGUzz. - Transferencias de riqueza $y$ efecto contagio ante crisis bancarias. Implicaciones para las relaciones banca-industria.

SANTIAGO ÁLVAREZ; MARÍA TERESA ÁLVAREZ.- Impuestos medio ambientales $y$ control de la generación de residuos. ¿Hacia una reforma fiscal verde?

JAVIER SUÁREZ PANDIELLO-- Rationality and rent seeking in the spanish regulation of professional soccer.

JAVIER SUÁREZ PANDIELLO. - Determinantes politicos del gasto público en España.

MANUEL A. AIBUERNE GOTIÉRREZ. - Estrategia de diversificación $y$ participación accionarial de los gestores: eficiencia supervisora VS atrincheramiento.

ANA SUÁRES VÁZQUEZ; JUAN A. TRESPALACIOS GUTIÉRREZ; IGNACIO A. RODRÍGUEZ DEL BOSQUE RODRÍGUEZ.- Elección de establecimientos comerciales: modelos compensatorios.

JOSÉ BAÑOS PINO; VÍCTOR FERNÁNDEZ BLANCO; ANA RODRÍGUEZ ÁLVAREZ. - The allocative efficiency measure by means of a distance function: the case of Spanish public railways.

LAURA GALGUERA GARCIA; ANA Ma CAMBLOR PORTILIA.- LAS tarjetas Milti-sponsor.

Ma ELENA FERNÁNDEZ RODRIGUZZ.- ACercamiento entre contabilidad $y$ fiscalidad tras la reforma del impuesto sobre sociedades: ¿Ficción o realidad?

SANTIAGO ÁLVAREZ GARCÍA; URSICINO CARRASCAL ARRANZ.- La reforma del IRPF y el tratamiento de la familia: El coste de los hijos $y$ su compensación mediante el minimo familiar. PILAR ARBESó Lópzz.- La descentralización y la consolidación de cuentas en el ámbito local.

CARMEN RAMOS CARVAJAL; $M$ JOSE PRESNO CASQUERO.- AlgunaS técnicas ajuste de coeficientes imput-output: una comparación.

LUIS IGNACIO ÁLVAREZ GONZÁLEZ; FERNÁNDO GONZÁLEZ ASTORGA; FRANCISCO JAVIER DE IA BALLINA BALLINA.- Orientación al mercado de las empresas de distribución comercial: Aplicación al caso de la cooperación espacial de detallistas.

IGNACIO DEL ROSAT FERNÁNDEZ.- LOS efectos sobre el bienestar de la politica carbonera en España, 1989-1995. 
Doc. $189 / 99$

Doc. $190 / 99$

Doc. $191 / 99$
Ma BELÉN ÁLVAREZ PÉREZ. - Reducción de problemas de agencia en las cooperativas: Mecanismos de salvaguardia.

ALBERTO FONSECA PEÑA.- Negociación y conflicto en el marco del GaTT. Un caso práctico bajo el prisma de la teoria de juegos.

CRISTINA LÓPEZ DUARTE; ESTEBAN GARCÍA CANAL.- EOYEING investors'choice of mode of entry: An integrative frameword. 